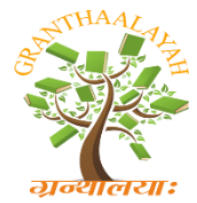

\author{
INTERNATIONAL JOURNAL OF RESEARCH \\ GRANTHAALAYAH \\ A knowledge Repository
}

Science

\title{
RAINWATER HARVESTING ON GREENHOUSE ROOF AND USE IN IRRIGATION
}

\author{
Sedat Boyacı *1, Sinan Kartal ${ }^{2}$ \\ ${ }^{* 1}$ Biosystems Engineering, Kirsehir Ahi Evran University, Turkey \\ ${ }^{2}$ Plant and Animal Production, Akdeniz University, Turkey
}

\begin{abstract}
Rainwater collection systems are alternative water supply methods providing environmental and economic benefits compared to traditional water supply methods used in arid and semi-arid climates with water shortages. Rainwater harvested in greenhouse roof by rain gutters can be used to irrigate and grow the plants cultivated in greenhouses. However, rain gutters and storage tanks in greenhouses should be of sufficient size to collect rainwater. Water consumption of plants in the greenhouse should be calculated correctly to determine the storage size in greenhouses. The amount of annual irrigation water harvested from rainfall in Kirsehir province where total rainfall is $388.31 / \mathrm{m} 2$ was determined as $349.57 \mathrm{l} / \mathrm{m} 2$ based on rainfall factor of 0.9 . Total amount of irrigation water needed by the plants in the unheated greenhouse between April and September for single crop cultivation was $568.33 \mathrm{l} / \mathrm{m} 2$. The results revealed that $61.49 \%$ of irrigation water needed for plants can be met by rainwater harvesting. In addition, $47.74 \%$ of the total water demand of plants in the heated greenhouse where crops are grown throughout a year can be met by rainwater harvesting. The storage capacities needed for unheated and heated greenhouses were determined as $0.21 \mathrm{~m} 3 / \mathrm{m} 2$ and $0.30 \mathrm{~m} 3 / \mathrm{m} 2$ depending on the amount of rainwater harvested. The results showed that rainwater harvesting may contribute to the improvement of agricultural activities in water-scarce regions.
\end{abstract}

Keywords: Greenhouse Cultivation; Irrigation Water; Rainwater Harvesting; Crop Water Requirement.

Cite This Article: Sedat Boyac1, and Sinan Kartal. (2019). "RAINWATER HARVESTING ON GREENHOUSE ROOF AND USE IN IRRIGATION." International Journal of Research - Granthaalayah, 7(2), 93-100. https://doi.org/10.29121/granthaalayah.v7.i2.2019.1011.

\section{Introduction}

Water harvesting is the collection and storage of surface runoff for various purposes in arid and semi-arid regions where commonly used sources such as streams or wells are scarce. The water harvesting systems, in addition to providing drinking water for human, animal and wildlife, can provide additional water for crop growth (Fraiser, 1980). Water resources in semi-arid and arid regions are the most important limiting factors of plant growth. Therefore, effective use of 
rainwater is one of the focal points of research carried out on water resources (Gao et al., 2009). The rainwater on greenhouse roof can be used to irrigate plants grown in the greenhouses if properly harvested and stored. Therefore, storage facilities with sufficient sizes should be provided for harvested rainwater. Plants which were grown in a greenhouse and known for the irrigation water demand can be grown using harvested rainwater (Olaifa, 2015). Irrigation water is a scarce factor in many regions of the world. Therefore, water requirement of crops should be calculated accurately and irrigation systems should be carefully designed. The information on evapotranspiration in a greenhouse is important for successful plant growth, calculation of irrigation water consumption, and deposition and storage of rainwater (von Zabeltitz, 2011). The scarcity of clean water that will arise in the future will be the most significant problem of sustainable agriculture in the Mediterranean climate zone. Excessive water in rainy periods and inadequate water for irrigation in dry periods are the water problems encountered in regions with different climatic conditions. The rainwater reaching the greenhouse roof during cultivation in a greenhouse can be collected and stored using water gutters. The rain gutters and tanks should be of sufficient size in greenhouses to collect rainwater. The water consumption in a greenhouse should be calculated correctly to determine the storage capacity of greenhouses (Baytorun, 2016). Rainwater harvesting (RWH) can be an effective alternative water supply solution in regions affected by severe water scarcity. The water harvesting recently become an important option for water supply in arid and semi-arid areas due to its benefits and cost-effectiveness (Liuzzo et al., 2016). Investigating potential new sources for irrigation can contribute to the development of more efficient agricultural activities by reducing the amount of irrigation water from costly public waters, wells, rivers or canals that can be extremely contaminated (Lupia and Pulighe, 2015).

This study was carried out to determine the ratio of harvested water to irrigation water demand of plants depending on water consumption per unit area in the heated and unheated greenhouses, and the required storage volume in the greenhouses.

\section{Materials and Methods}

\subsection{Determination of Crop Water Demand}

Evapotranspiration can be calculated by the FAO-Penman-Monteith method which was used for open field conditions (Allen et al. 1998). The Penman-Monteith equation for a reference evapotranspiration $\mathrm{ET}_{\mathrm{o}}$, derived from an energy balance Equation 1 for an evaporating surface of a well-irrigated grass reference crop is:

$$
\mathrm{ET}_{\mathrm{o}}=\frac{0.408 \times \Delta\left(\mathrm{q}_{\mathrm{RN}}-\mathrm{q}_{\mathrm{RG}}\right)+\gamma \frac{900}{\mathrm{~T}_{\text {mean }}+273} \times \mathrm{v} \times\left(\mathrm{e}_{\mathrm{s}}-\mathrm{e}_{\mathrm{a}}\right)}{\Delta+\gamma(1+0.34 \mathrm{v})}
$$

Where: $\mathrm{Et}_{\mathrm{o}}$ is the reference evapotranspiration (mm/day), $\Delta=\mathrm{f}\left(\mathrm{T}_{\text {mean }}\right)$ is the slope of vapor pressure curve $\left(\mathrm{kPa} /{ }^{\circ} \mathrm{C}\right)$, given in the table (Annex 2, Allen et al. 1998), $\mathrm{\gamma}=\mathrm{f}$ (altitude $\mathrm{z}$ ) is the psychometric constant $\left(\mathrm{kPa} /{ }^{\circ} \mathrm{C}\right.$ ), given in the table (Annex 2, Allen et al. 1998), $\mathrm{q}_{\mathrm{RN}}$ is the net radiation at crop surface $\left(\mathrm{MJ} / \mathrm{m}^{2}\right.$ day), $\mathrm{q}_{\mathrm{RG}}$ is the soil heat flux density that is very small and can normally be neglected $\left(\mathrm{MJ} / \mathrm{m}^{2}\right.$ day), $\mathrm{v}$ is the air speed $(\mathrm{m} / \mathrm{s}), \mathrm{e}_{\mathrm{s}}$ is the saturation vapor pressure $\mathrm{f}(\mathrm{Tmean}),(\mathrm{kPa})$, given in the table (Annex 2, Allen et al. 1998), $\mathrm{e}_{\mathrm{a}}$ is the actual vapor pressure, $\mathrm{f}(\mathrm{Tmean}),(\mathrm{kPa})$. 
The mean minimum and maximum temperatures for the calculation of evapotranspiration inside a greenhouse can be assumed as in be Equations 2, 3 and 4 (von Zabeltitz, 2011):

$\mathrm{T}_{\mathrm{gmax}}=\mathrm{T}_{\max }+4$

$\mathrm{T}_{\mathrm{gmin}}=\mathrm{T}_{\min }+2$

$\mathrm{T}_{\text {gmean }}=\left(\mathrm{T}_{\text {gmax }}+\mathrm{T}_{\text {gmin }}\right) / 2$

Where: $\mathrm{T}_{\text {gmax }}$ is the mean maximum temperature $\left({ }^{\circ} \mathrm{C}\right), \mathrm{T}_{\mathrm{gmin}}$ is the mean minimum temperature $\left({ }^{\circ} \mathrm{C}\right)$ and $\mathrm{T}_{\text {gmean }}$ is the mean temperature $\left({ }^{\circ} \mathrm{C}\right)$.

The outside temperature values for the unheated greenhouse were calculated according to the longterm climate data. The mean maximum and minimum temperatures for the greenhouse heated throughout the year were determined as $16-20{ }^{\circ} \mathrm{C}$.

The crop water requirement (CWR) can be calculated by using the reference evapotranspiration ETo (mm/day) according to FAO-Penman-Monteith with adapted parameters for the unheated greenhouses (Allen et al. 1998). The actual evapotranspiration (AET) of the crop inside a greenhouse was calculated by Equation 5, daily crop water requirement was calculated by using Equation 6 and monthly crop water requirement by Equation 7.

$\mathrm{AET}_{\mathrm{c}}=\mathrm{ET}_{\mathrm{o}} \mathrm{x} \mathrm{k}_{\mathrm{c}}$

$\mathrm{CWR}_{\mathrm{d}}=\operatorname{AET}\left(1+\mathrm{l}_{\mathrm{i}}\right) \times \mathrm{A}_{\text {crop }} / \mathrm{AG}$

$\mathrm{CWR}_{\mathrm{m}}=\mathrm{CWR}_{\mathrm{d}} \mathrm{X} \mathrm{dm}$

Where: $\mathrm{AET}_{\mathrm{c}}$ is the actual crop evapotranspiration $\left(\mathrm{mm} /\right.$ day $=1 / \mathrm{m}^{2}$ day), $\mathrm{k}_{\mathrm{c}}$ is the crop coefficients (calculated mean $\left.\mathrm{k}_{\mathrm{c}}=1.1\right), \mathrm{CWR}_{\mathrm{d}}$ is the daily crop water requirement $(\mathrm{mm} / \mathrm{day}), \mathrm{l}_{\mathrm{i}}$ is between 0.03 and 0.1 loss factor for the drip irrigation system, $A_{\text {crop }} / A G=0.9$ for vegetables and flowers on ground beds, $\mathrm{CWR}_{\mathrm{m}}$ is the monthly crop water requirement ( $\left.\mathrm{mm} / \mathrm{month}\right)$ and $\mathrm{d}_{\mathrm{m}}$ is the days in a month.

\subsection{Calculation of the Storage Volume}

Monthly total precipitation was calculated by using Equation 8.

$\mathrm{CVm}=$ Pre $\mathrm{x} f \mathrm{c}$

Where: $\mathrm{CVm}$ is the monthly total precipitation ( $1 / \mathrm{m}^{2}$ month), Pre ( $1 / \mathrm{m}^{2}$ month) is the mean monthly precipitation and $\mathrm{fc}=0.9$ that is the collecting factor for greenhouse roofs.

If rain water is used for irrigation, the monthly storable precipitation can be calculated as:

$\mathrm{STP}_{\mathrm{m}}=\mathrm{CV}_{\mathrm{m}}-\mathrm{CWR}_{\mathrm{m}}-\mathrm{EV}_{\text {pond }}\left(1 / \mathrm{m}^{2}\right.$ month $)$ 
Where: STPm is the monthly storable precipitation $\left(1 / \mathrm{m}^{2}\right.$ month), $\mathrm{EV}_{\text {pond }}$ is the evaporation of storage basin surface which can be neglected if the basin is covered by a swimming plastic cover.

If $\mathrm{STP}_{\mathrm{m}}$ is positive, the storage will be filled, if $\mathrm{STP}_{\mathrm{m}}$ is negative, the storage will be emptied.

The yearly storable precipitation was calculated by;

STPy $=$ spositive STPm $\left(1 / \mathrm{m}^{2}\right.$ month $)$

The yearly deficit was calculated by;

Defy $=$ ¿negative STPm $\left(1 / \mathrm{m}^{2}\right.$ month $)$

The yearly storage balance was calculated by;

STBy $=$ STPy - Defy $\left(1 / \mathrm{m}^{2}\right.$ month $)$

\section{Results and Discussions}

\subsection{Air Conditioning Months and Status of Agricultural Structure}

Full time heating is needed for greenhouses in Kurşehir province for about 4.5 months from midOctober to mid-March, and also 2 months of night time heating is needed from mid-March to midApril and from the beginning of October to the end of November. Natural ventilation for about 4 months is needed from the middle of April to the end of June and from the beginning of August to the first weeks of October. The ventilation+cooling is needed for about 1.5 months starting from the end of June until the beginning of August (Figure 3.1).

Crops can be grown in the greenhouses of Kırşehir province for six months between April and September without heating. Cultivation is not economical for the rest of the year due to the high costs of fossil fuels used for heating. The cost of heating in the second place among the production costs thus, heating increases the production costs. However, plant production in the greenhouses can be possible throughout the year by using the existing geothermal water resources of the province for heating the greenhouses. The use of geothermal water will reduce the share of heating in production costs and make the vegetable production in cold season appropriate for the region.

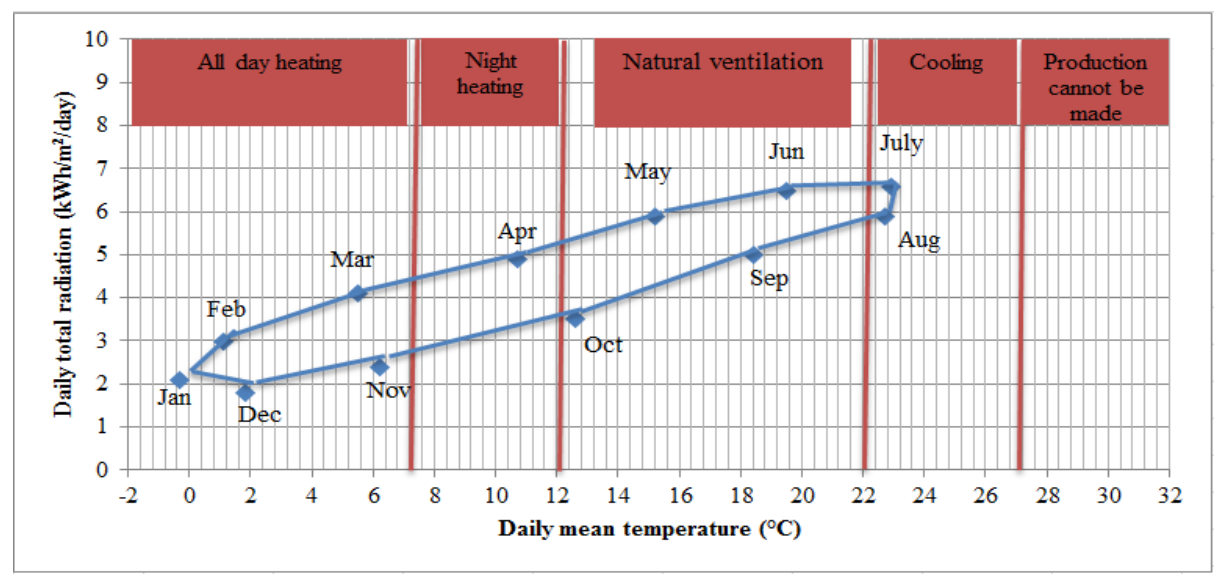

Figure 3.1: Months which will need air conditioning 
The annual total amount of rainfall per square meter in Kırşehir province, where the continental climate is dominated, is 388.2 liters. Dry farming practices are used for agricultural production in open fields of the province where the rainfall is very low. The geothermal water resources located in some part of the province where irrigation water is very important cause problems to producers in exploring the cold-water resources. However, part of the irrigation water needed by the plants can be met by rainwater harvesting.

The species belonged to the Solanaceous family (tomato, pepper and eggplant) constitute approximately $60 \%$ of the products grown in the greenhouses. The tomato is the most investigated plant among the crops grown in greenhouses (Katsoulas and Kittas, 2008). Despite the recent increase of greenhouse production in Kırşehir province, some producers produce single crop a year from April to September due to the high heating costs. However, producers benefiting from geothermal energy sources continue to produce throughout the year. The most widely grown product in Kurşehir province as in the world and the rest of the country is tomato. Annual tomato production is 4714 tons and this corresponds to $99 \%$ of the products grown in the province.

\subsection{Amount of Irrigation Water Demand in the Unheated Greenhouse}

The amount of irrigation water required for the tomato plant in the unheated greenhouses between April and September revealed that the ETo values ranged from 2.69 to $3.641 / \mathrm{m}^{2} /$ day (Figure 3.2).

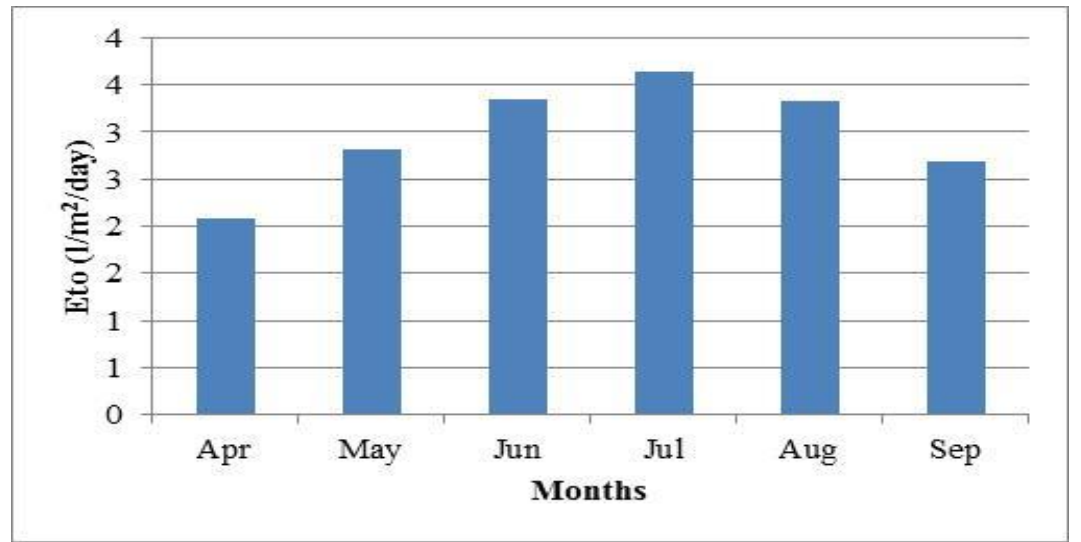

Figure 3.2: Eto values calculated using the adapted Penman-Monteith equation

Storage volume of the unheated greenhouse was given in Table 3.1. The irrigation water demand of tomato plants indicates that monthly $\mathrm{CWR}_{\mathrm{m}}$ values vary between 64.90 and 117.35 $\left(1 / \mathrm{m}^{2} / \mathrm{month}\right)$.

Table 3.1: Unheated greenhouses data calculation of the storage volume in Kırşehir (Turkey)

\begin{tabular}{|c|c|c|c|c|c|c|c|}
\hline Months & $\begin{array}{c}\text { Pre } \\
\left(1 / \mathrm{m}^{2} \text { month }\right)\end{array}$ & $\begin{array}{c}\text { CV } \\
\left(1 / \mathbf{m}^{2} \text { month }\right)\end{array}$ & $\begin{array}{c}\text { dm } \\
\text { days }\end{array}$ & $\begin{array}{c}\text { Eto } \\
\left(1 / \mathbf{m}^{2} \text { month }\right)\end{array}$ & $\begin{array}{c}\text { CWR }_{\mathrm{m}} \\
\left(\mathrm{l} / \mathrm{m}^{2} \text { month }\right)\end{array}$ & $\begin{array}{c}\mathrm{STP}_{\mathrm{m}} \\
\left(\mathrm{l} / \mathrm{m}^{2} \text { month }\right)\end{array}$ & $\begin{array}{c}\mathrm{STP}_{\mathrm{m}} \\
\text { accumulated }\end{array}$ \\
\hline January & 45.10 & 40.59 & 31.00 & & & 40.59 & 144.00 \\
\hline February & 34.70 & 31.23 & 28.00 & & & 31.23 & 175.23 \\
\hline March & 37.60 & 33.84 & 31.00 & & & 33.84 & 209.07 \\
\hline April & 45.00 & 40.50 & 30.00 & 2.08 & 64.90 & -24.40 & 184.67 \\
\hline May & 45.10 & 40.59 & 31.00 & 2.81 & 90.59 & -50.00 & 134.67 \\
\hline
\end{tabular}




\begin{tabular}{|l|l|l|l|l|l|l|l|} 
June & 36.10 & 32.49 & 30.00 & 3.35 & 104.52 & -72.03 & 62.64 \\
\hline July & 8.90 & 8.01 & 31.00 & 3.64 & 117.35 & -109.34 & -46.70 \\
\hline August & 7.10 & 6.39 & 31.00 & 3.32 & 107.04 & -100.65 & -147.35 \\
\hline September & 13.80 & 12.42 & 30.00 & 2.69 & 83.93 & -71.51 & -218.86 \\
\hline October & 29.60 & 26.64 & 31.00 & & & 26.64 & 26.64 \\
\hline November & 37.90 & 34.11 & 30.00 & & & 34.11 & 34.11 \\
\hline December & 47.40 & 42.66 & 31.00 & & & 42.66 & 76.77 \\
\hline
\end{tabular}

The amount of water stored by rainwater harvesting in the greenhouse between the October and March was 209.07 1/m² (Table 3.1). Accordingly, the storage volume for $1 \mathrm{~m}^{2}$ of the greenhouse area is VST $=\mathrm{STPy}=209.07\left(1 / \mathrm{m}^{2}\right)=0.21 \mathrm{~m}^{3} / \mathrm{m}^{2}$. The storage tanks in greenhouses will remain empty for 3 months from July to September. Because the amount of irrigation water stored in these months cannot meet the water demands of the plants.

\subsection{Amount of irrigation water demand in the heated greenhouse}

Considering the amount of irrigation water needed by the plants in the case of plant growth throughout the year, daily ETo values in greenhouses vary between 0.73 and $3.001 / \mathrm{m}^{2} /$ day (Figure 3.3).

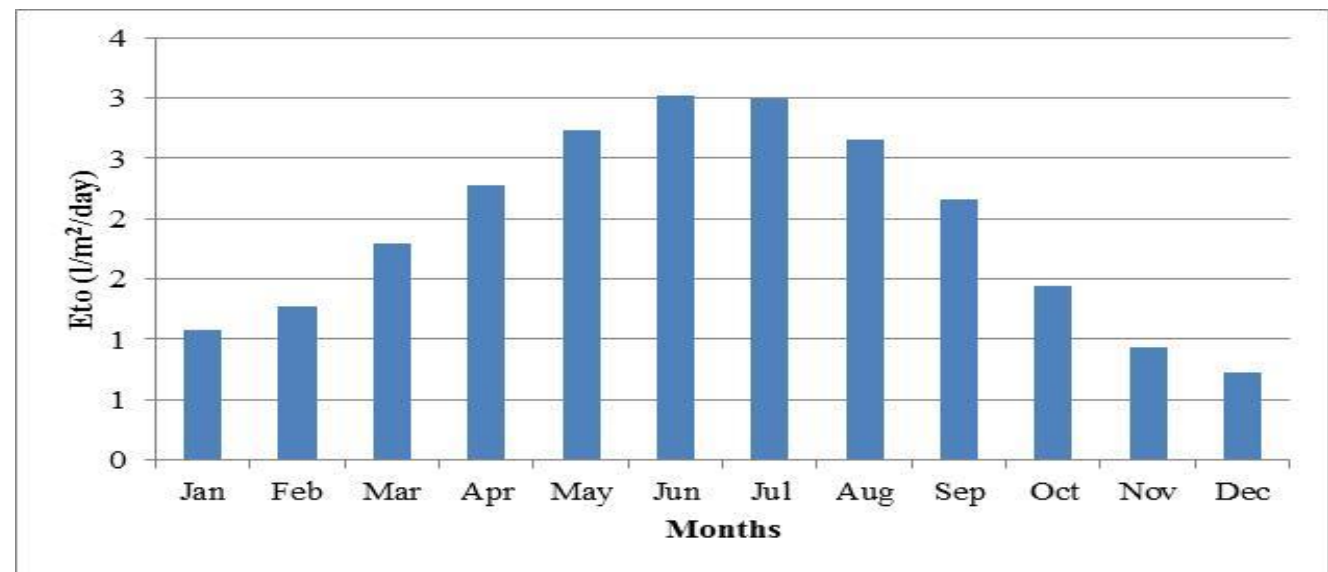

Figure 3.3: Eto values calculated using the adapted Penman-Monteith equation

The storage volume of the greenhouse where crops grow throughout the year was presented in Table 3.2. The irrigation water demand of tomato plants reveals that monthly $\mathrm{CWR}_{\mathrm{m}}$ values range from 23.54 to $96.72\left(1 / \mathrm{m}^{2} / \mathrm{month}\right)$.

Table 3.2: Heated greenhouses data calculation of the storage volume in Kırşehir (Turkey)

\begin{tabular}{|c|c|c|c|c|c|c|c|}
\hline Months & $\begin{array}{c}\text { Pre } \\
\left(\mathbf{l} / \mathbf{m}^{2} \text { month }\right)\end{array}$ & $\begin{array}{c}\text { CV } \\
\left(\mathbf{l} / \mathrm{m}^{2} \text { month }\right)\end{array}$ & $\begin{array}{c}\text { dm } \\
\text { days }\end{array}$ & $\begin{array}{c}\text { Eto } \\
\left(1 / \mathbf{m}^{2} \text { month }\right)\end{array}$ & $\begin{array}{c}\text { CWR }_{\mathrm{m}} \\
\left(\mathbf{l} / \mathbf{m}^{2} \text { month }\right)\end{array}$ & $\begin{array}{c}\mathbf{S T P}_{\mathrm{m}} \\
\left(\mathbf{l} / \mathbf{m}^{2} \text { month }\right)\end{array}$ & $\begin{array}{c}\mathbf{S T P}_{\mathrm{m}} \\
\text { accumulated }\end{array}$ \\
\hline January & 45.10 & 40.59 & 31.00 & 1.08 & 34.82 & 5.77 & 29.67 \\
\hline February & 34.70 & 31.23 & 28.00 & 1.28 & 37.27 & -6.04 & 23.63 \\
\hline March & 37.60 & 33.84 & 31.00 & 1.79 & 57.71 & -23.87 & -0.24 \\
\hline April & 45.00 & 40.50 & 30.00 & 2.28 & 71.14 & -30.64 & -30.88 \\
\hline May & 45.10 & 40.59 & 31.00 & 2.74 & 88.34 & -47.75 & -78.63 \\
\hline
\end{tabular}




\begin{tabular}{|l|l|l|l|l|l|l|l|} 
June & 36.10 & 32.49 & 30.00 & 3.02 & 94.22 & -61.73 & -140.36 \\
\hline July & 8.90 & 8.01 & 31.00 & 3.00 & 96.72 & -88.71 & -229.07 \\
\hline August & 7.10 & 6.39 & 31.00 & 2.66 & 85.76 & -79.37 & -308.44 \\
\hline September & 13.80 & 12.42 & 30.00 & 2.16 & 66.77 & -54.35 & -362.79 \\
\hline October & 29.60 & 26.64 & 31.00 & 1.44 & 46.43 & -19.79 & -382.58 \\
\hline November & 37.90 & 34.11 & 30.00 & 0.94 & 29.33 & 4.78 & 4.78 \\
\hline December & 47.40 & 42.66 & 31.00 & 0.73 & 23.54 & 19.12 & 23.90 \\
\hline
\end{tabular}

The amount of water stored by rainwater harvesting in the greenhouse between November and January was $29.67 \mathrm{l} / \mathrm{m}^{2}$ (Table 3.2). Accordingly, the storage volume for $1 \mathrm{~m}^{2}$ of the greenhouse area is VST $=\mathrm{STPy}=29.67\left(1 / \mathrm{m}^{2}\right)=0.30 \mathrm{~m}^{3} / \mathrm{m}^{2}$. The storage tanks in greenhouses will remain empty for 8 months from March to October. Because the amount of irrigation water stored in these months cannot meet the water demands of the plants.

The amount of annual irrigation water that can be obtained by rainwater harvest in Kurşehir province where the total rainfall is $388.3 \mathrm{l} / \mathrm{m}^{2}$, is $349.57 \mathrm{l} / \mathrm{m}^{2}$ considering the rainfall factor of 0.9 . The total amount of irrigation water required by the plants in the unheated greenhouse between April and September is $568.33 \mathrm{l} / \mathrm{m}^{2}$. According to this, $61.49 \%$ of the irrigation water needed for plants can be met by rainwater harvesting. Besides, $47.74 \%$ of the total water needs of plants, which is $732.05 \mathrm{l} / \mathrm{m}^{2}$ in the greenhouse heated throughout the year can be met by rainwater harvesting.

The countries are classified for the amount of available fresh water per capita per year as follow; water poor for $<1000 \mathrm{~m}^{3}$, water shortage between 1000 and $2000 \mathrm{~m}^{3}$ and water rich for $>8000 \mathrm{~m}^{3}$ (DSİ, 2019). Turkey is not a country rich in available fresh water. Turkey is classified as a country with water shortage according to the annual amount of fresh water per capita. The annual amount of available fresh water per capita is around $1519 \mathrm{~m}^{3}$. The annual average total available water potential of the country is 112 billion $\mathrm{m}^{3}$ of which $16 \%$ is consumed in drinking and using, $12 \%$ in industry and $72 \%$ in agricultural irrigation (DSI, 2019). The most important factor in the management of water resources is agricultural irrigation. Increasing water use efficiency in irrigation is of great importance in water conservation (Çakmak et al., 2008). The decrease in the amount and quality of water resources for various reasons increased the efforts to find alternative water sources, and the use of wastewater and rainwater harvesting in agriculture are the leading alternatives (Ahi and Gültaş, 2018). Water harvesting structures have the potential to increase the productivity of arable lands by reducing the risk of crop failure and increasing the crop production in arid and semi-arid areas where water deficiency is common (Örs et al., 2011). High water surplus for irrigation during rainy seasons and water deficit during dry seasons are very common in many regions of the country. Rainwater flowing from the roofs of greenhouses can be collected and used for irrigation during plant growth in greenhouses. If there is saline water, the collected fresh rainwater can be mixed with saline water, and then used as irrigation water. Greenhouses with large rain gutters and storage tanks should be constructed to collect rainwater. The amount of irrigation water demand is required to calculate the storage for rainwater and irrigation systems (von zabeltitz, 2011). Rainwater harvesting is a relatively inexpensive, small scale water supply method that can be adapted to the local resources and demands of rural communities and small households. Xiao-Yan Li (2003) reported that the development of rainwater collection systems is essential for efficient, sustainable and highly productive agriculture. 


\section{Conclusions and Recommendations}

The results of study indicated that large portion of irrigation water demand in heated (61.49\%) and unheated (47.74\%) greenhouses in Kirşehir province where rainfall is very low can be met by rainwater harvesting in the greenhouses. The storage capacity of the unheated greenhouse was determined as $0.21 \mathrm{~m}^{3} / \mathrm{m}^{2}$ and $0.30 \mathrm{~m}^{3} / \mathrm{m}^{2}$ for the heated greenhouse. The rain gutters and storage tanks must be of sufficient size in greenhouses to increase the efficiency of rainwater harvesting. The advantages of the system include the low maintenance and operating costs of rain gutters except the first investment costs during the greenhouse construction, the ease of supply and installation of rain gutters with the developing technologies, the integration of the rainwater with the irrigation system to be used in the greenhouse and the protection of existing water resources. Besides, harvested waters should be filtered prior to using in the irrigation system due to the sediments in harvested water and the pollution risk factors occurring during the storage should be minimized.

\section{References}

[1] Ahi, Y. and Gültaş, HT. Current techniques and technologies in agricultural water management, Agriculture and Engineering. 1, 2018, 72-76. (in Turkish).

[2] Allen, G., Pereira, LS., Raes, D. and Smith, M. Crop evapotranspiration, Guidelines for computing crop water requirements. FAO irrigation and drainage paper No. 56 FAO, Rome

[3] Baytorun AN., Greenhouses. Nobel academic publishing. 2016, 415. (in Turkish)

[4] Çakmak, B., Yıldırım, M. and Aküzüm, A. Irrigation management in Turkey, problems and solutions, TMMOB 2. Water Policy Conference, 2008, Ankara/Turkey. (in Turkish)

[5] [5] Frasier, GW. Harvesting water for agricultural, wildlife, and domestic uses, J. Soil Water Cons. 35, 1980, 125-128.

[6] Gao, P., Li, Z.J., Zhang, G.C. and Liu, ZX. Rainwater efficient use of the cellar-greenhouse system on slope land in hilly semi-arid area of North China, Plant Soil Environ. 55, 2009, 146-153.

[7] DSİ. General directorate of state hydraulic works. Retrieved from [Online]. Available at: http://www.dsi.gov.tr/toprak-ve-su-kaynaklari (2019).

[8] Katsoulas, N. and Kittas, C. Impact of greenhouse microclimate on plant growth and development with special reference to the solanaceae, The European journal of plant science and Biotechnology. 2, 2008, 31-44.

[9] Olaifa, O.P., Abegunrin, T.P., Chukwudebe, E.P., Zaccheaus, O. S., Balogun, A.C. and Ande, SA. Incorporating rain water harvesting into the greenhouse farming, Journal of Information Engineering and Applications. 5, 2015, 84-88.

[10] Von Zabeltitz, C., 2011. Integrated greenhouse systems for mild climates. Springer-Verlag Berlin Heidelberg 2011. 360.

*Corresponding author.

E-mail address: sedat.boyaci@ ahievran.edu.tr 